\title{
Review
}

\section{Flavonoids: A new generation molecule to stimulate programmed cell deaths in cancer cells.}

\author{
Venu Venkatarame Gowda Saralamma ${ }^{1 \dagger}$, Eun Hee Kim ${ }^{3 \dagger}$, Ho Jeong Lee ${ }^{1}$, Suchismita Raha ${ }^{1}$, Won Sup Lee ${ }^{2}$, Jeong Doo \\ $\mathrm{Heo}^{4}$, Sang Joon Lee ${ }^{4}$, Chun-Kil Won ${ }^{5}$, Gon-Sup Kim ${ }^{1 *}$ \\ ${ }^{1}$ Research Institute of Life science and College of Veterinary Medicine, Gyeongsang National University, Jinju, 52828, Korea \\ ${ }^{2}$ Department of Internal Medicine, Institute of Health Sciences, Gyeongsang National University School of Medicine, Jinju, \\ 52727, Korea \\ ${ }^{3}$ Department of Nursing Science, International University of Korea, Jinju, 52833, Korea \\ ${ }^{4}$ Gyeongnam Department of Environment Toxicology and Chemistry, Toxicity Screening Research Center, Korea Institute of \\ Toxicology, Jinju, Korea \\ ${ }^{5}$ College of Veterinary Medicine, Gyeongsang National University, Jinju 52828, Korea \\ ${ }^{\dagger}$ Authors have contributed equally to complete this study.
}

Programmed cell death (PCD) is decisive in eliminating affected cells in human cancers, whereas there are increasing cases of cancer-related death due to side effects of modern treatment methods. There is an urge for new methods of growth inhibition and elimination of cancer cells with a lower cytotoxicity to normal cells. Irregularity along PCD pathways plays a crucial role in cancer cell carcinogenesis. Apoptosis is a distinct cell death mechanism occurring in multicellular organisms and also called type one programmed cell death. Autophagy and paraptosis are non-apoptotic PCD occurring in multicellular organisms. Natural compounds are the fundament of pharmacological treatments, and flavonoids are natural polyphenolic compounds which are unique due to their diverse chemical structures and various biological active mechanisms like anticancer, anti-inflammatory, antioxidative and much more. This gives an increasing number of studies indicating that some flavonoids from medicinal plants could be promising candidates for new natural anticancer drugs, which attract high interests of academic researchers and advanced users. An understanding of the underlying mechanism of PCD induced by flavonoids in cancer cells is important as it plays a pivotal role in the pathogenesis of many diseases. This systematic review is to report flavonoids and their derivatives as new anticancer candidates to stimulate PCD with a different mechanism based on the pharmacological evidence.
Key words: flavonoids, apoptosis, autophagy, paraptosis, cancer cells, caspases

\section{Introduction}

Cancer is being the second leading cause of mortality worldwide, and it is expected to overcome heart diseases as the leading cause of death in few years [1-4]. It is pivotal to understand the detailed mechanisms of advancement in cancer therapy that induce death in cancer cells. One of the most effective cancer therapy methods is induction of programed cell death (PCD) using various cytotoxic agents to eradicate cancer cells [5-8]. To date, various natural products have been reported to confer anticancer effects by inducing PCD like apoptosis, autophagy, and paraptosis-associated cell death [9-13].

Flavonoids are naturally occurring polyphenolic metabolites which are primarily benzo- $\gamma$-pyrone (phenyl chromone) derivatives, distributed throughout the plant kingdom and found in an substantial amount in fruits, vegetables, grains, nuts, seeds, tea, and traditional medicinal herbs. These natural compounds constitute more than 4,000 chemically unique and distinct moieties [13, 14]. Flavonoids have been classified according to their molecular structure that consists of two benzene rings joined by a linear three-carbon chain and forms an oxy-

\footnotetext{
*Corresponding author: Gon Sup Kim,

College of Veterinary Medicine, Gyeongsang National University, Jinju 52828, Korea

Tel: +82-55-772-2346, Fax: +82-55-772-2349, E-mail: gonskim@gnu.ac.kr
} 
genated heterocycle (C6-C3-C6), and their large number of derivatives arise from the various combinations of multiple hydroxyl, methoxyl, and O-glycoside group substituents on the basic benzo- pyrone (C6-C3-C6). These excessively diverse group of compounds broadly comprise distinct classes such as flavonols, flavans, proanthocyanidins, anthocyanidins, flavanones, flavones, isoflavones, and neoflavonoids [15, 16] (Fig. 1). Within individual plants, flavonoids occur concentrated in the leaves and flowers but it is in every part of the plant. Flavonoids are edible plant pigments responsible for much of the coloring in nature. It has been estimated that an average daily intake of mixed flavonoids in human beings was in the range of 0.5 to $1 \mathrm{~g}$, expressed as glycosides [17]. Many of the different flavonoids are part of the regular human diet. Although they are nonessential dietary factors, flavonoids are thought to be nutritionally valuable compounds, being the key natural products that provide an essential link between the diet and prevention of chronic disorders. One of the most investigated activities of flavonoids is their contribution to cancer prevention and treatment $[14,18]$.

The previous studies demonstrated flavonoid extracts, as well as their monomers, have covered a broad spectrum of biological activities like antioxidantion, anti-inflammation and anticancer. Flavonoids exhibited anti-cancer activity by inducing several PCD mechanisms with lower cytotoxicity in normal cells indicating their cancer-specific cytotoxicity in different cancer cells [13, 19-30]. It is imperative to understand the molecular mechanisms in which flavonoids triggered the activation of PCD in cancer cells.

Induction of apoptosis by flavonoids in cancer cells Apoptosis and necrosis are two distinct cell death mechanisms that occur in multicellular organisms. Apoptosis also called PCDs which play a critical role in hormonedependent atrophy, metamorphosis, and embryonic development as well as in the maintenance of tissue homeostasis. Apoptosis occurs mainly in two pathways, the extrinsic or death receptor pathway which is triggered by the death receptor-like Fas, a member of the tumor necrosis factor (TNF) receptor superfamily, and intrinsic or mitochondrial pathway that leads to the release of cytochrome-c from the mitochondria. Both the pathways assemble to a common point where caspase-3, an effector caspase of apoptosis, is activated. Activated caspase-3 is responsible for the cleavage of poly (ADP-ribose) polymerase (PARP) that leads to cleavage of several cellular and structural molecules related to DNA regulation and repair (Fig. 2) [6, 8, 31, 32]. Plenty of literature suggests that irregularity along apoptotic pathways plays a crucial role in cancer cell carcinogenesis. Studies have shown that apoptosis can eliminate potentially malignant cells and inhibit tumor progression and hyperplasia [33]. There are several ways in which malignant cells can acquire reduction in apoptosis or apoptosis resistance. The mechanisms by which the evasion of apoptosis occurs broadly by three ways: 1) disrupted balance of pro-apoptotic and anti-apoptotic proteins, 2) reduced caspase function, and 3 ) impaired death receptor signaling. Targeting pathways which induce cancer cell apoptosis is one of the molecu-<smiles>O=C(C=Cc1ccccc1)OC(=O)c1ccccc1O</smiles>

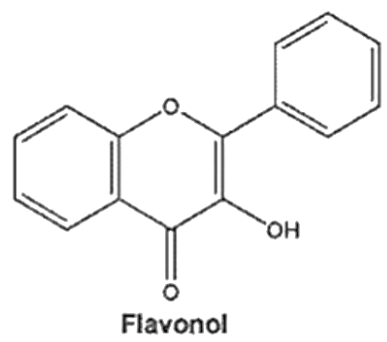<smiles>O=C1CC(c2ccccc2)Oc2ccccc21</smiles><smiles>O=c1c(-c2ccccc2)coc2ccccc12</smiles><smiles>O=C1c2ccccc2O[C@H](c2ccccc2)C1O</smiles>

Flavanonol<smiles>OC1Cc2ccccc2OC1c1ccccc1</smiles>

Flavan-3-ol<smiles>O=c1cc(-c2ccccc2)oc2ccccc12</smiles><smiles>O=c1ccc2ccccc2o1</smiles>

Fig. 1. General structures of representative flavonoids [69]. 
lar target therapies in a modern era of cancer treatment. Natural products are known to have potential anticancer effects by targeting the multiple cellular signaling pathways like apoptosis. Many studies showed that flavonoid extracts and its monomers have a regulatory effect on cell cycle arrest and apoptosis of cancer cells. Disruption in the balance of anti-apoptotic and pro-apoptotic members of the Bcl-2 family leads to dysregulated apoptosis in the affected cells. Flavonoids have been reported to regulate $\mathrm{Bcl}-2$ family proteins by up-regulating proapoptotic protein and by down-regulating anti-apoptotic proteins, leading to apoptosis in several cancer cells [25, 34-39]. The p53 protein, also called tumor protein 53, is known as tumor suppressor protein. The p53 functions as a transcription factor regulating downstream genes that are important in cell cycle arrest, DNA repair, and apoptosis. Several studies showed that mutation in this gene in several cancer cells leads to resistance to the induction apoptotic cell death of cancer cells [7, 40-42]. Several drugs have been investigated to target p53 via different mechanisms. The flavonoids are such molecules which regulate p53 in several cancer cells and induce cell cycle arrest and apoptosis which helps to inhibit cancer cell growth [43, 44]. The inhibitor of apoptosis proteins (IAPs) are a group of structurally and functionally similar proteins that regulate cytokinesis, signal transduction,

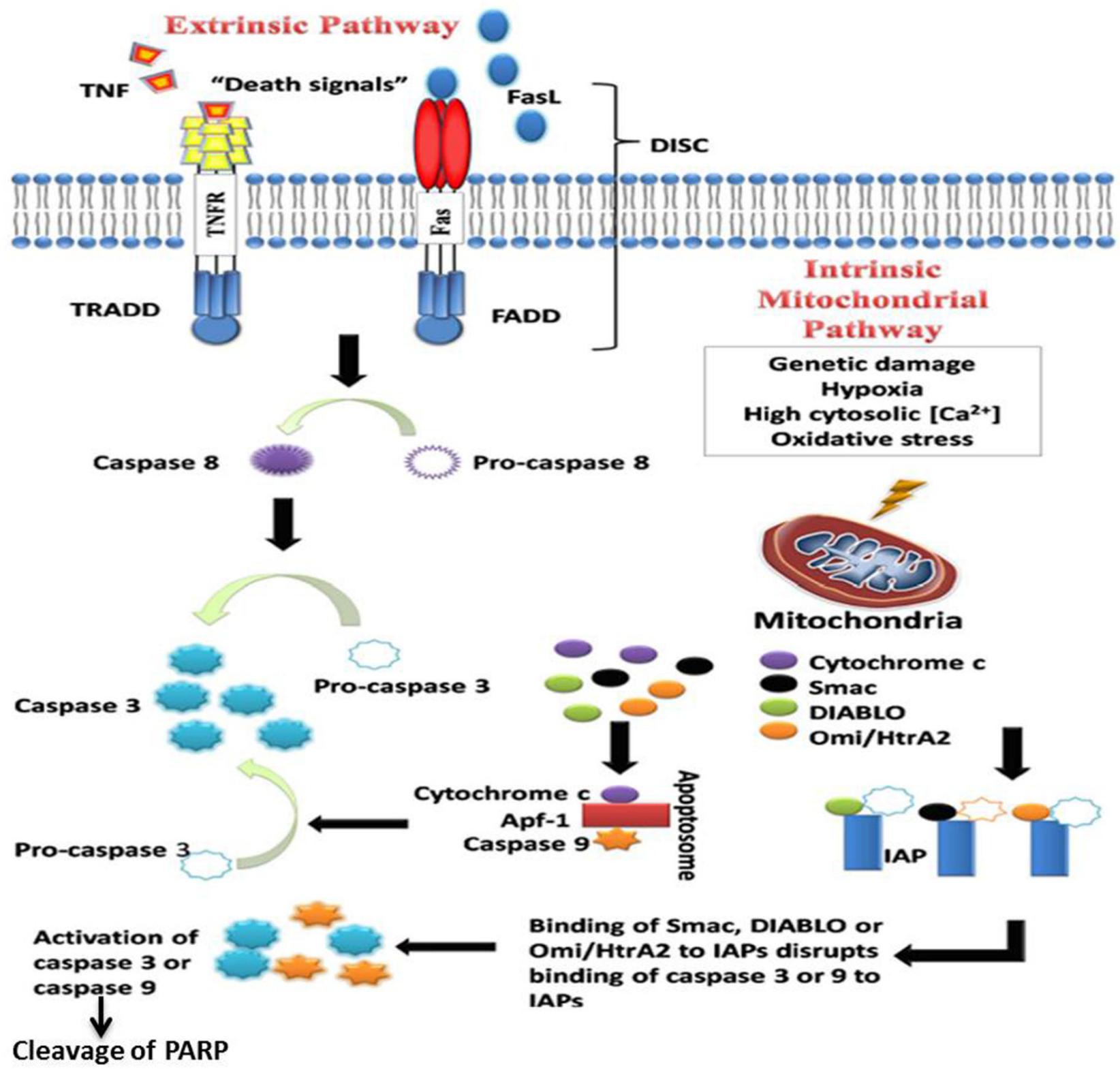

Fig. 2. The intrinsic and extrinsic pathways of apoptosis [70]. 
and apoptosis. IAPs are subjective inhibitors of caspases, and they can inhibit caspase activity by binding their conserved BIR domains to the active sites of caspases, leading to degradation of active caspases. A distinct amount of studies has shown the dysregulated IAP expression in several cancers $[45,46]$. The IAPs are attractive molecular targets to promote apoptosis in cancer cells. Cancer cells treated with flavonoid have down-regulated the expressions of several IAPs and induces both extrinsic and intrinsic pathway of apoptosis in cancer cells [12, $38,47]$. Activation of caspases remains one of the important players in the initiation and execution of apoptosis $[8,29,31,48]$. Studies have revealed that cancer cells treated with flavonoids induce apoptosis by activating both initiator caspases (e.g. caspase-2, -8, -9 and -10) which are primarily responsible for the initiation of the apoptotic pathway and effector caspases (caspase-3, -6 and -7) which are responsible for the actual cleavage of cellular components during apoptosis [20, 21, 25, 34]. Ligands of the death receptors and death receptors are key players in the extrinsic pathway of apoptosis. These receptors possess a death domain, and when triggered by a death signal, a number of molecules are attracted to the death domain, resulting in the activation of a signaling cascade. Flavonoid treated cancer cells regulated death ligands and their receptors and induced apoptosis in several cancer cells $[29,34,49,50]$.

\section{Induction of autophagy by flavonoids in cancer cells}

Autophagy is defined as type II PCD which is a ubiquitous physiological process in eukaryotic cells. The most common form of autophagy is known as macroautophagy. Autophagy is characterized by the formation of doublemembrane vesicles known as autophagosomes that inundate cytoplasmic constituents including organelles followed by maturation process upon fusion with lysosomes and which finally lead to becoming autolysosomes, which undergoes a cellular degradation led by a lysosomal enzyme in response to stress and starvation. Abundant literature suggests that autophagy promotes cancer cell death in response to various anticancer agents on apoptosis-resistant cells $[11,51,52]$. Several studies have reported that flavonoid induces autophagy cell death by altering key regulators of autophagy-like PI3K/Akt (protein kinase B)/mTOR [22, 28, 30, 53]. Induction of autophagic cell

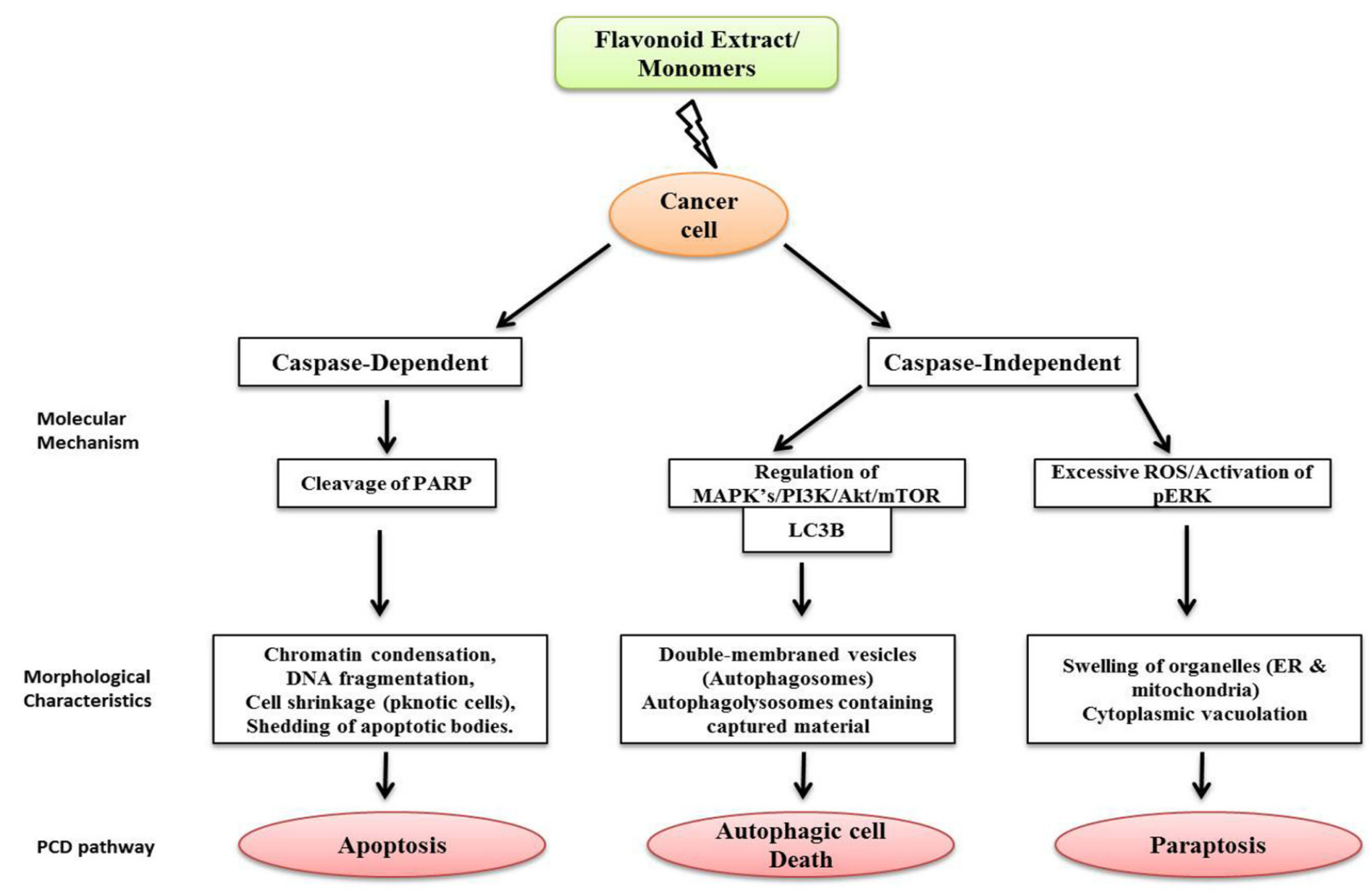

Fig. 3. Comparison of three types of Programmed Cell (PCD) Pathways in cancer cells treated with Flavonoid extracts/ flavonoid monomers. 
death by flavonoid in cancer cells could be triggered by mitogen-activated protein kinases (MAPKs) and increase in reactive oxygen species (ROS) of which both play a crucial role in the induction of autophagic cell death in tumor cells [54-57].

\section{Induction of paraptosis by flavonoids in cancer cells}

Cellular resistance to apoptosis in anti-cancer therapies is closely associated with carcinogenesis in many cancers. Studies have shown that failure of apoptosis leads to the trigger of many non-apoptotic cell death mechanisms and may contribute to tumor cell death [58-60]. Paraptosis, a non-apoptotic PCD is characterized by cytoplasmic vacuolization derived from endoplasmic reticulum (ER) and/ or mitochondrial swelling, lack of apoptotic morphology, lack of DNA fragment, lack of caspase activation, lack of inhibition by caspase inhibitors (z-VAD.fmk, p35, and $\mathrm{XIAP}$ ) and Bcl-XL, and lack of poly (ADP-ribose) polymerase (PARP) cleavage [61, 62]. In this type of cell death, the formation of apoptotic bodies, or other characteristics of apoptotic morphology such as chromatin condensation and DNA fragmentation are absent. Paraptosis cell death, that may be induced by the insulin-like growth factor I (IGF-1) receptor, is mediated by MAPKs and triggered by induction of ROS [26, 63-66]. Natural compounds are the fundament of pharmacological treatments, and more than $60 \%$ of all anticancer drugs are of natural origins or at least derived from areas present in nature [10, 13, 67]. Natural flavonoids have shown induction of paraptosis through the phosphorylation of ERK1/2 and increase of ROS production and loss of membrane potential which finally lead to paraptotic cell death in cancer cells [27, 68]. Study results revealed that; flavonoid can stimulate an alternative form of apoptosis in apoptotic resistant cancer cells for anti-cancer therapies.

\section{Conclusions}

Cancer in humans caused by continual DNA damage has an increasing global concern of health care for over few decades. The modern treatments like chemotherapy and radiotherapy have their own limitation including cancer resistance against anticancer drugs and side effects due to radiotherapy. Hence, there is a need to develop an effective method to treat the cancer cell growth which is uncontrolled due to modifications of base pairs in DNA without causing damage to normal cells. The studies discussed in this review give an insight that flavonoids can play important beneficial roles in human health and nutritional status. Flavonoids play a crucial role in eliminating cancer cells by inducing cancer specific PCD with lower cytotoxicity, which gives a promising and most realistic chemopreventive approach for malignant disorders. There is a lack of knowledge about diet-healthy relationships, where flavonoids usually act through multiple pathways, and each flavonoid can have different molecular targets and mechanisms on both cancer and normal cells. Phytochemical combinations may offer greater chemoprevention than administration of single agent alone. It is decisive to find out the optimal concentration of flavonoids from a treatment point of view considering that higher concentrations of flavonoids which may be cytotoxic to normal cells. Due to their versatile nature of cancer-specific cytotoxicity, flavonoids make them attractive agents in anticancer drug discovery (Fig. 3.). However, more studies need to be carried out to construct the mechanism of action of this selective nature of flavonoids in order to understand various epigenetic process which will provide a rational basis for combining specific dietary compounds and enhancing efficacy in the clinical setting.

\section{Acknowledgements}

This work was supported by Development Fund Foundation, Gyeongsang National University, 2015 and National Research Foundation of Korea (NRF) funded by the Ministry of Science, ICT \& Future Planning (No.2017R1A2B4003974).

\section{ORCID}

Gon Sup Kim, http://orcid.org/0000-0001-7048-458X

\section{References}

1. Siegel RL, Miller KD, Jemal A. Cancer statistics, 2016. CA: a cancer journal for clinicians 2016; 66(1):7-30.

2. Jung KW, Won YJ, Kong HJ, Oh CM, Cho H, Lee DH, Lee KH.Cancer statistics in Korea: incidence, mortality, survival, and prevalence in 2012. Cancer research and treatment : official journal of Korean Cancer Association 2015;47(2):127-141.

3. Torre LA, Bray F, Siegel RL, Ferlay J, Lortet-Tieulent J, Jemal A. Global cancer statistics, 2012. CA: a cancer journal for clinicians 2015;65(2):87-108.

4. Ferlay J, Soerjomataram I, Dikshit R, Eser S, Mathers C, Rebelo M, Parkin DM, Forman D, Bray F. Cancer incidence and mortality worldwide: sources, methods and major patterns in GLOBOCAN 2012. International journal of cancer 2015;136(5):E359-386.

5.Ludwig LM, Nassin ML, Hadji A, LaBelle JL. Killing Two Cells with One Stone: Pharmacologic BCL-2 Family Targeting for Cancer Cell Death and Immune Modulation. Frontiers in pediatrics 2016;4:135.

6. Danial NN, Korsmeyer SJ. Cell death: critical control points. Cell 2004;116(2):205-219. 
7. Ghobrial IM, Witzig TE, Adjei AA. Targeting apoptosis pathways in cancer therapy. CA: a cancer journal for clinicians 2005;55(3):178-194.

8. Taylor RC, Cullen SP, Martin SJ. Apoptosis: controlled demolition at the cellular level. Nature reviews Molecular cell biology 2008;9(3):231-241.

9. Hacker G. The morphology of apoptosis. Cell and tissue research 2000;301(1):5-17.

10. Newman DJ, Cragg GM. Natural products as sources of new drugs over the 30 years from 1981 to 2010 . Journal of natural products 2012;75(3):311-335.

11. Law BY, Chan WK, Xu SW, Wang JR, Bai LP, Liu L, Wong VK. Natural small-molecule enhancers of autophagy induce autophagic cell death in apoptosisdefective cells. Scientific reports 2014;4:5510.

12. Hyun HB, Lee WS, Go SI, Nagappan A, Park C, Han MH, Hong SH, Kim G, Kim GY, Cheong J et al. The flavonoid morin from Moraceae induces apoptosis by modulation of Bcl-2 family members and Fas receptor in HCT 116 cells. International journal of oncology 2015;46(6):2670-2678.

13. Gontijo VS, Dos Santos MH, Viegas C, Jr. Biological and Chemical Aspects of Natural Biflavonoids from Plants: a Brief Review. Mini reviews in medicinal chemistry 2016.

14. Bode AM, Dong Z. Signal transduction and molecular targets of selected flavonoids. Antioxidants \& redox signaling 2013;19(2):163-180.

15. Heim KE, Tagliaferro AR, Bobilya DJ. Flavonoid antioxidants: chemistry, metabolism and structure-activity relationships. The Journal of nutritional biochemistry 2002;13(10):572-584.

16. Corradini E, Foglia P, Giansanti P, Gubbiotti R, Samperi R, Lagana A. Flavonoids: chemical properties and analytical methodologies of identification and quantitation in foods and plants. Natural product research 2011; 25(5):469-495.

17. Kuhnau J. The flavonoids. A class of semi-essential food components: their role in human nutrition. World review of nutrition and dietetics 1976;24:117-191.

18. Liu HL, Jiang WB, Xie MX. Flavonoids: recent advances as anticancer drugs. Recent patents on anti-cancer drug discovery 2010;5(2):152-164.

19. Hughes SD, Ketheesan N, Haleagrahara N. The Therapeutic Potential of Plant Flavonoids on Rheumatoid Arthritis. Critical reviews in food science and nutrition 2016;0.

20. Nagappan A, Lee HJ, Saralamma VV, Park HS, Hong GE, Yumnam S, Raha S, Charles SN, Shin SC, Kim $\mathrm{EH}$ et al. Flavonoids isolated from Citrus platymamma induced $\mathrm{G} 2 / \mathrm{M}$ cell cycle arrest and apoptosis in A549 human lung cancer cells. Oncology letters 2016; 12(2):1394-1402.
21. Xuan HZ, Zhang JH, Wang YH, Fu CL, Zhang W. Anti-tumor activity evaluation of novel chrysin-organotin compound in MCF-7 cells. Bioorganic \& medicinal chemistry letters 2016;26(2):570-574.

22. Chen J, Yuan J, Zhou L, Zhu M, Shi Z, Song J, Xu Q, Yin G, Lv Y, Luo Y et al. Regulation of different components from Ophiopogon japonicus on autophagy in human lung adenocarcinoma A549Cells through PI3K/ Akt/mTOR signaling pathway. Biomedicine \& pharmacotherapy 2016;87:118-126.

23. Sung NY, Kim MY, Cho JY. Scutellarein Reduces Inflammatory Responses by Inhibiting Src Kinase Activity. The Korean journal of physiology \& pharmacology : official journal of the Korean Physiological Society and the Korean Society of Pharmacology 2015;19(5):441449.

24. Zhang Z, He L, Lu L, Liu Y, Dong G, Miao J, Luo P. Characterization and quantification of the chemical compositions of Scutellariae Barbatae herba and differentiation from its substitute by combining UHPLCPDA-QTOF-MS/MS with UHPLC-MS/MS. Journal of pharmaceutical and biomedical analysis 2015;109:6266.

25. Lee DH, Park KI, Park HS, Kang SR, Nagappan A, Kim JA, Kim EH, Lee WS, Hah YS, Chung HJ et al. Flavonoids Isolated from Korea Citrus aurantium L. Induce G2/M Phase Arrest and Apoptosis in Human Gastric Cancer AGS Cells. Evidence-based complementary and alternative medicine : eCAM 2012;2012:515901.

26. Asare N, Landvik NE, Lagadic-Gossmann D, Rissel M, Tekpli X, Ask K, Lag M, Holme JA. 1-Nitropyrene (1-NP) induces apoptosis and apparently a non-apoptotic programmed cell death (paraptosis) in Hepa1c1c7 cells. Toxicology and applied pharmacology 2008; 230(2):175-186.

27. Yumnam S, Park HS, Kim MK, Nagappan A, Hong GE, Lee HJ, Lee WS, Kim EH, Cho JH, Shin SC et al. Hesperidin induces paraptosis like cell death in hepatoblastoma, HepG2 Cells: involvement of ERK1/2 MAPK [corrected]. PloS one 2014;9(6):e101321.

28. Raha S, Yumnam S, Hong GE, Lee HJ, Saralamma VV, Park HS, Heo JD, Lee SJ, Kim EH, Kim JA et al. Naringin induces autophagy-mediated growth inhibition by downregulating the PI3K/Akt/mTOR cascade via activation of MAPK pathways in AGS cancer cells. International journal of oncology 2015;47(3):1061-1069.

29. Saralamma VV, Nagappan A, Hong GE, Lee HJ, Yumnam S, Raha S, Heo JD, Lee SJ, Lee WS, Kim EH et al. Poncirin Induces Apoptosis in AGS Human Gastric Cancer Cells through Extrinsic Apoptotic Pathway by up-Regulation of Fas Ligand. International journal of molecular sciences 2015;16(9):22676-22691.

30. Li YR, Li S, Ho CT, Chang YH, Tan KT, Chung TW, Wang BY, Chen YK, Lin CC. Tangeretin derivative, 5-acetyloxy-6,7,8,4'-tetramethoxyflavone induces 
G2/M arrest, apoptosis and autophagy in human nonsmall cell lung cancer cells in vitro and in vivo. Cancer biology \& therapy 2016;17(1):48-64.

31. Logue SE, Martin SJ. Caspase activation cascades in apoptosis. Biochemical Society transactions 2008; 36(Pt 1):1-9.

32. Saraste A, Pulkki K. Morphologic and biochemical hallmarks of apoptosis. Cardiovascular research 2000; 45(3):528-537.

33. Kerr JF, Wyllie AH, Currie AR. Apoptosis: a basic biological phenomenon with wide-ranging implications in tissue kinetics. British journal of cancer 1972; 26(4):239-257.

34. Banjerdpongchai R, Wudtiwai B, Khawon P. Induction of Human Hepatocellular Carcinoma HepG2 Cell Apoptosis by Naringin. Asian Pacific journal of cancer prevention : APJCP 2016;17(7):3289-3294.

35.Zhang Q, Ma S, Liu B, Liu J, Zhu R, Li M. Chrysin induces cell apoptosis via activation of the p53/ Bcl-2/caspase-9 pathway in hepatocellular carcinoma cells. Experimental and therapeutic medicine 2016; 12(1):469-474.

36. Mu J, Liu T, Jiang L, Wu X, Cao Y, Li M, Dong Q, Liu $\mathrm{Y}, \mathrm{Xu} \mathrm{H}$. The Traditional Chinese Medicine Baicalein Potently Inhibits Gastric Cancer Cells. Journal of Cancer 2016;7(4):453-461.

37. Zhang SD, Shan L, Li W, Li HL, Zhang WD. Isochamaejasmin induces apoptosis in leukemia cells through inhibiting Bcl-2 family proteins. Chinese journal of natural medicines 2015;13(9):660-666.

38. Yang PY, Hu DN, Lin IC, Liu FS. Butein Shows Cytotoxic Effects and Induces Apoptosis in Human Ovarian Cancer Cells. The American journal of Chinese medicine 2015;43(4):769-782.

39. Haque A, Rahman MA, Chen ZG, Saba NF, Khuri FR, Shin DM, Ruhul Amin AR. Combination of erlotinib and EGCG induces apoptosis of head and neck cancers through posttranscriptional regulation of Bim and Bcl2. Apoptosis : an international journal on programmed cell death 2015;20(7):986-995.

40. Avery-Kiejda KA, Bowden NA, Croft AJ, Scurr LL, Kairupan CF, Ashton KA, Talseth-Palmer BA, Rizos $\mathrm{H}$, Zhang XD, Scott RJ et al. P53 in human melanoma fails to regulate target genes associated with apoptosis and the cell cycle and may contribute to proliferation. BMC cancer 2011;11:203.

41. Levine AJ. p53, the cellular gatekeeper for growth and division. Cell 1997;88(3):323-331.

42. Lane DP. Cancer. p53, guardian of the genome. Nature 1992;358(6381):15-16.

43. Lee CF, Yang JS, Tsai FJ, Chiang NN, Lu CC, Huang YS, Chen C, Chen FA. Kaempferol induces ATM/p53mediated death receptor and mitochondrial apoptosis in human umbilical vein endothelial cells. International journal of oncology 2016;48(5):2007-2014.

44. Hirchaud F, Hermetet F, Ablise M, Fauconnet S, Vuitton DA, Pretet JL, Mougin C. Isoliquiritigenin induces caspase-dependent apoptosis via downregulation of HPV16 E6 expression in cervical cancer Ca Ski cells. Planta medica 2013;79(17):1628-1635.

45. Silke J, Meier P. Inhibitor of apoptosis (IAP) proteinsmodulators of cell death and inflammation. Cold Spring Harbor perspectives in biology 2013;5(2):a008730.

46. LaCasse EC, Mahoney DJ, Cheung HH, Plenchette S, Baird S, Korneluk RG. IAP-targeted therapies for cancer. Oncogene 2008;27(48):6252-6275.

47. Peng XH, Karna P, O'Regan RM, Liu X, Naithani R, Moriarty RM, Wood WC, Lee HY, Yang L. Down-regulation of inhibitor of apoptosis proteins by deguelin selectively induces apoptosis in breast cancer cells. Molecular pharmacology 2007;71(1):101-111.

48. Shi Y. Caspase activation: revisiting the induced proximity model. Cell 2004;117(7):855-858.

49. Saxena N, Yadav P, Kumar O. The Fas/Fas ligand apoptotic pathway is involved in abrin-induced apoptosis. Toxicological sciences : an official journal of the Society of Toxicology 2013;135(1):103-118.

50. Henkler F, Behrle E, Dennehy KM, Wicovsky A, Peters N, Warnke C, Pfizenmaier K, Wajant H. The extracellular domains of FasL and Fas are sufficient for the formation of supramolecular FasL-Fas clusters of high stability. The Journal of cell biology 2005; 168(7):1087-1098.

51. Chen YJ, Chi CW, Su WC, Huang HL. Lapatinib induces autophagic cell death and inhibits growth of human hepatocellular carcinoma. Oncotarget 2014; 5(13):4845-4854.

52. Towers CG, Thorburn A. Therapeutic Targeting of Autophagy. EBioMedicine 2016;14:15-23

53. Tsai JP, Lee CH, Ying TH, Lin CL, Lin CL, Hsueh JT, Hsieh YH. Licochalcone A induces autophagy through $\mathrm{PI} 3 \mathrm{~K} / \mathrm{Akt} / \mathrm{mTOR}$ inactivation and autophagy suppression enhances Licochalcone A-induced apoptosis of human cervical cancer cells. Oncotarget 2015; 6(30):28851-28866.

54. Hsieh MJ, Chen MK, Chen CJ, Hsieh MC, Lo YS, Chuang YC, Chiou HL, Yang SF. Glabridin induces apoptosis and autophagy through JNK1/2 pathway in human hepatoma cells. Phytomedicine : international journal of phytotherapy and phytopharmacology 2016; 23(4):359-366.

55. Zhang L, Cheng X, Gao Y, Zheng J, Xu Q, Sun Y, Guan $\mathrm{H}, \mathrm{Yu} \mathrm{H}$, Sun Z. Apigenin induces autophagic cell death in human papillary thyroid carcinoma BCPAP cells. Food \& function 2015;6(11):3464-3472.

56. Jiang K, Wang W, Jin X, Wang Z, Ji Z, Meng G. Silibinin, a natural flavonoid, induces autophagy via ROSdependent mitochondrial dysfunction and loss of ATP 
involving BNIP3 in human MCF7 breast cancer cells. Oncology reports 2015;33(6):2711-2718.

57. Yuan L, Wei S, Wang J, Liu X. Isoorientin induces apoptosis and autophagy simultaneously by reactive oxygen species (ROS)-related p53, PI3K/Akt, JNK, and p38 signaling pathways in HepG2 cancer cells. Journal of agricultural and food chemistry 2014;62(23):53905400 .

58. Ubah OC, Wallace HM. Cancer therapy: Targeting mitochondria and other sub-cellular organelles. Current pharmaceutical design 2014;20(2):201-222.

59. Tait SW, Ichim G, Green DR. Die another way--nonapoptotic mechanisms of cell death. Journal of cell science 2014;127(Pt 10):2135-2144.

60. Blank M, Shiloh Y. Programs for cell death: apoptosis is only one way to go. Cell cycle 2007;6(6):686-695.

61. Clarke PG. Developmental cell death: morphological diversity and multiple mechanisms. Anatomy and embryology 1990;181(3):195-213.

62. Sperandio S, de Belle I, Bredesen DE. An alternative, nonapoptotic form of programmed cell death. Proceedings of the National Academy of Sciences of the United States of America 2000;97(26):14376-14381.

63. Sperandio S, Poksay K, de Belle I, Lafuente MJ, Liu B, Nasir J, Bredesen DE. Paraptosis: mediation by MAP kinases and inhibition by AIP-1/Alix. Cell death and differentiation 2004;11(10):1066-1075.

64. Li B, Zhao J, Wang CZ, Searle J, He TC, Yuan CS, Du W. Ginsenoside Rh2 induces apoptosis and paraptosis- like cell death in colorectal cancer cells through activation of p53. Cancer letters 2011;301(2):185-192.

65. Wang Y, Xu K, Zhang H, Zhao J, Zhu X, Wang Y, Wu $\mathrm{R}$. Retinal ganglion cell death is triggered by paraptosis via reactive oxygen species production: a brief literature review presenting a novel hypothesis in glaucoma pathology. Molecular medicine reports 2014; 10(3):1179-1183.

66. Ghosh K, De S, Das S, Mukherjee S, Sengupta Bandyopadhyay S. Withaferin A Induces ROS-Mediated Paraptosis in Human Breast Cancer Cell-Lines MCF-7 and MDA-MB-231. PloS one 2016;11(12):e0168488.

67. Uzoigwe J, Sauter ER. Cancer prevention and treatment using combination therapy with plant- and animal-derived compounds. Expert review of clinical pharmacology 2012;5(6):701-709.

68. Yumnam S, Hong GE, Raha S, Saralamma VV, Lee HJ, Lee WS, Kim EH, Kim GS. Mitochondrial Dysfunction and $\mathrm{Ca}(2+)$ Overload Contributes to Hesperidin Induced Paraptosis in Hepatoblastoma Cells, HepG2. Journal of cellular physiology 2016;231(6):1261-1268.

69. Lago JH, Toledo-Arruda AC, Mernak M, Barrosa KH, Martins MA, Tiberio IF, Prado CM. Structure-activity association of flavonoids in lung diseases. Molecules 2014;19(3):3570-3595.

70. Wong RS. Apoptosis in cancer: from pathogenesis to treatment. Journal of experimental \& clinical cancer research : CR 2011;30(1):87. 